\title{
Between Efficiency and Sufficiency: The Optimal Combination of Policy Instruments in the Mobility Sector towards Sustainable Development
}

\author{
Ursula Mauch, Nicole North, and Raffael Pulli
}

There is a consensus within environmental science that sustainable development can be achieved only through a combination of varying instruments, including environmental policy instruments. The present contribution examines so-called sufficiency and efficiency strategies in the mobility sector.

Efficiency, or "eco-efficiency", strategies are linked to technological innovations, such as the catalytic converter or the three-litre engine, but also to price increases on petrol, which all ultimately aim towards an increase in resource efficiency. In the main, efficiency strategies are implemented through economic or command and control instruments. In contrast, sufficiency approaches always contain an element of renunciation of resource use, such as when people give up the use of private vehicles. Sufficiency means more intensive utilisation or shared utilisation of goods, as in car sharing schemes, for example. Sufficiency strategies are frequently implemented through service and infrastructure instruments and through communication and diffusion instruments.

In this chapter, we analyse such service and infrastructure instruments as car sharing ("Mobility Switzerland") as well as approaches based on communication and diffusion instruments, such as Global Action Plan for the Earth (GAP) and the Model Bicycle City of Münsingen (Velomodellstadt Münsingen: Veloville). We compare the ecological effects of these efforts to the effects that can be achieved through economic and command and control instruments. The focus of the inquiry is the issue of the optimal combination of instruments to reduce the volume of traffic and, thus, traffic's serious environmental impact. 


\section{Introduction}

\subsection{Background}

\subsubsection{A debate on concepts of sustainability}

In the framework of the recent scientific and sociopolitical discourse on models, concepts, and strategies of sustainable development, two trains of thought stand out (see, among others, Hofmeister, 1999):

- The conceptual-strategic approach using the efficiency principle. This is known as the "harder" sustainability strategy. Methodologically, the strategy is manifested in approaches that seek to measure and increase resource productivity and resource efficiency. The challenge is directed principally towards producers of goods.

- The conceptual-strategic approach emphasising the "sufficiency principle" as the "softer" sustainability strategy. At the level of resource management, however, this strategy has basically the same aims. The challenge is directed in the main to consumers to alter their life styles and shift to more sustainable patterns of consumption.

The two approaches share the goal to alleviate environmental problems by means of a reduction in resource and energy turnover. In this way, both approaches are quantity-oriented. While the efficiency strategy seeks to boost the productivity of raw material resources, the sufficiency strategy targets a change in consumption behaviour. To overstate the case somewhat, we can say that both approaches prescribe restriction and renunciation (Hofmeister et al., 1999a).

Researchers today agree that sustainable development can be achieved only through a combination of efficiency and sufficiency strategies. From a political perspective, however, there are fundamental contradictions relating to the scientific consensus. Representatives of industry and liberal economists take the efficiency strategy approach and demand that corresponding economic instruments be implemented to provide incentives (via the price mechanism) for increasing efficiency (BCSD, 1994). Others conclude that in addition, or even principally, a real change in sufficiency has to occur for environmental and resource consumption not to exceed the carrying capacities of ecological systems. Environmental policy measures that follow the sufficiency approach are mostly service and infrastructure instruments or communication instruments.

\subsubsection{Individual mobility as a core problem}

The struggle for environmentally sustainable solutions is most evident in the mobility sector. In Switzerland, transport is the main producer of $\mathrm{CO} 2$ emissions, is a major source of noise pollution, and consumes approximately $33 \%$ of the total final energy consumption. Compared to 1980, transport-related energy consumption has increased by 50\%. Between 1980 and 1995 the energy demand for private transport rose by $20 \%$. The total distance travelled by the Swiss per year is 100 billion kilometres (billion = a thousand million, or 109). The growth in the sector is 
mainly due to private motorised transport (BUWAL and BFS, 1997). The greatest part of the total distance travelled is leisure time travel; of 100 kilometres travelled, 50 are travelled in leisure time, while only 25 make up the commute to work or school. The remaining $25 \%$ are split equally between shopping and business trips. On average, each person travels 34 kilometres a day, travelling $20 \%$ of this distance by public transportation. Three-quarters of all households have one or more cars (BFS, 1999). There is thus a great need for action in the mobility sector to reduce energy consumption, particularly in view of national and international policies on the impact on climate.

Various solution attempts to make transport more environmentally sustainable involve efficiency and sufficiency approaches. For example, technological innovations, such as the catalytic converter or the three-litre engine car, as well as the implementation of economic instruments, such as fuel price increases, are measures to increase efficiency and reduce resource use. Conscious renunciation of personal vehicle ownership with a shift to public transportation or a carsharing organisation are examples of the sufficiency approach.

\subsection{Guiding questions and aim of this contribution}

Until a few years ago, it seemed unlikely that the political process would approve the implementation of government incentives through economic instruments to increase resource efficiency. ${ }^{1}$ This led to increased promotion and implementation of instruments that integrate a sufficiency strategy and, thus, a voluntary component. The main force behind this movement were private actors and local authorities rather than the cantons or the federal government.

Our main interest in this chapter is directed to instruments that show the characteristics of the sufficiency strategy. On the one hand, the goal of these instruments is to reduce traffic levels and thus traffic's impacts on the environment; on the other hand, the instruments aim to effect a change in the goals and knowledge of the target group towards more sustainable patterns of mobility behaviour. The main issues to be examined are:

- What are the ecological effects of these instruments with regard to energy savings and emissions reduction (outcome)?

- How can the ecological effects of these instruments be reinforced by combining them optimally with economic and command and control instruments of the efficiency strategy type (implemented by the government)?

This might have changed had the proposals for energy taxes been approved by voters in September 2000. The $\mathrm{CO}_{2}$ Law that passed in mid 2000 makes a provision for a $\mathrm{CO}_{2}$ tax by 2004, should $\mathrm{CO}_{2}$ target values not be reached by then. The $\mathrm{CO}_{2}$ Law would raise the price of petrol by CHF 0.50 per litre. 
Following a detailed presentation and evaluation of the efficiency and sufficiency strategies in section 2, section 3 investigates selected sufficiency strategy instruments in the mobility sector with regard to ecological effects as well as to success factors and barriers. We will look at car sharing (Mobility CarSharing Switzerland), the Household EcoTeam Programme of the Global Action Plan for the Earth (GAP), and the Model Bicycle City of Münsingen (Veloville). Following a comparative analysis of the ecological effects of the different instruments, we draw conclusions regarding the optimal combination of efficiency and sufficiency strategies and the corresponding instruments in section 4.

\section{Two approaches for sustainable development}

\subsection{More prosperity - less resource consumption: The efficiency revolution}

How can you raise the standard of living and at the same time lower resource consumption? This is possible only if each economic activity results in more advantages and less environmental impact, which means that fewer resources are implemented more efficiently. This is the strategy that is associated with the "efficiency revolution".

Pointing the way in 1995, the Wuppertal Institute proposed an increase in resource efficiency, or resource productivity, by a factor of four to ten in the next 30 to 50 years in industrialised countries. The book Factor Four: Doubling Wealth, Halving Resource Use (Weizsäcker et al., 1997) presents fifty examples of at least quadrupling resource productivity (energy use, materials use). Since then, the goal of factor four to ten has found tremendous resonance at the international level. Austria incorporated the concept into its environmental policy planning, and Finland and Sweden are discussing it at the programme level. In 1997, the special session of the General Assembly of the United Nations took over the Factor Four goal.

The resource efficiency of the total economy can be measured via the ratio of gross national product and the quantity of primary materials used. It is important to take into account that this efficiency measure is not a direct expression of the absolute level of resource use (both can increase with strong economic growth). However, it is just this level of resource use that must be reduced for actual alleviation of environmental impact (Bringezu, 1999). Efficiency increases are quickly negated by growth effects ("rebound effect"). The best example is cars. Through technological improvements in fuel efficiency, the average fuel consumption of cars per 100 kilometres dropped 10\% from 1980 to 1998, while at the same time the total fuel consumption by cars increased by $30 \%$. A rise in fuel efficiency from 10 kilometres per litre to 33 kilometres per litre (= 3 litres per 100 kilometres) is simply not enough. Ultimately, polluting carbon fuels will have to be replaced. There is not enough to be gained ecologically by constructing ever more efficient internal combustion engines, because fossil fuel reserves will inevitably be depleted, even if at a later date. What is more, environmental degradation has not been halted. From this perspective, the efficiency approach is not innovative (Hofmeister et al., 1999). 
All in all the efficiency revolution, as described in Factor Four, is not yet taking place or is progressing very slowly. The main reasons for this lie in incorrect incentive structures or a lack of them in society as well as distortion and failure of the market, for example through subsidies. Moreover, investments to improve efficiency compete against other investments that can return yields of $15 \%$ per annum. Conserving resources would have to produce similar yields, and with today's structure of the economy, that is possible only in small sub-sectors (Schumacher, 1997). The call for the efficiency revolution is thus in the main linked to implementation of economic instruments that, via the price mechanism, create incentives to increasing efficiency and that are held to be cost-efficient altogether.

\subsection{New models of prosperity: The sufficiency revolution}

The strategy of sufficiency goes back to the debate in the 1970s on self-limitation or - practically unanimously rejected - restriction through coercion. Sufficiency always entails the foregoing of personal material goods and consumption. It points to a new conception of affluence that is not measured in income or expenditures, but focuses on qualitative goals (fulfilment, solidarity, community, clean environment, and so on) that are to be implemented in a new lifestyle and new means of production. The new models of affluence attempt to make a simple, modest lifestyle socially acceptable that relieves the strain on the environment and hurts no one. Of all the goals, the highest priority is given to protection and conservation of the natural environment.

Granted, implementation of this guiding model is doubtful in the face of the lack of positive resonance in society. This idealistic approach, which involves modest consumption and the kind of wealth that is based in a stronger orientation to moral values, does not have much of a chance to gain a political majority. This is most certainly the case on the global scale (see here, among others, Fischer, 1995).

Sufficiency also means, however, that individuals and the community more frequently ask themselves if material possessions are truly necessary to well being. And they ask whether certain goods might be utilised more intensively. Telephones, lawnmowers, photocopy machines, televisions, computers, and cars are things that many people only wish to use. Under the strategies for more intensive use, there are numerous options for community use of goods through renting, sharing, or borrowing. Common (simultaneous) use is already the norm in many areas: from the "invisible" utility systems for water, electricity, telephone, and sewage; to public roads, parks, forests, and lakes; to aeroplanes, trains, buses and trams, concert halls and cinema theatres; to company car pooling. Divided use (in temporal succession) of goods is also practised in many areas: part-ownership of company planes; taxi companies; video rentals; launderettes; time-sharing through car sharing associations (see here section 3), washing rooms in multiplefamily homes; or sharing of tools among neighbours (compare Bringezu, 1999 and Stahel, 1999). 
Unnoticed by many economists, large markets for divided, or shared, use have already developed today. For example, time-sharing of holiday flats has become a worldwide business with a turnover of approximately CHF 6 billion. In addition, many routes to more intensive use of resources, such as sharing or borrowing, are taken by self-help groups and co-operatives, which means that they take place outside the monetary economy (Stahel, 1999).

More intensive, shared use of resources avoids unnecessary waste and can bring economic gains to the users. Shared and more intensive utilisation goes hand in hand with the principle of "using with care", and it bases principally on trust. Misuse may result in expulsion from the "community". Shared utilisation thus supports a shift in participants' values towards sustainability.

\subsection{From efficiency and sufficiency towards consistency?}

The discussion on efficiency and sufficiency has paved the way for a third strategy, called the consistency strategy. Figuratively, consistency means compatibility, acceptability, coherence, agreement. Consistency does not focus primarily on reducing resource use through efficiency gains or renunciation, but rather aims at sustainable management of resources, in very large volumes, through a comprehensively conceived, closed economic cycle. Here the consistency strategy aims at the development of basic innovations that open up fundamentally new paths of technological and product development (compare, among others, Huber, 1995, or Hofmeister et al., 1999a). An example of innovation of this kind is the fuel cell, as opposed to traditional car engines or combustion plants; fuel cells produce no or low emissions. A step further is taken with the general transition from fossil fuels to hydrogen, in the form of solar hydrogen, for instance (Hofmeister et al., 1999a).

Establishing consistency while at the same time increasing efficiency is also the goal of integrated environmental protection according to ISO 14000 standards. This route is no longer a matter of "end of pipe" measures for aftercare of the environment. These standards dictate integrated, proactive protection of the environment. Here possible negative environmental impact is taken into account from the very start of the planning of a product (Schumacher, 1997).

Through the aid of any of the three strategies of efficiency, sufficiency, or consistency alone the goal of environmental acceptability does not seem achievable. A meaningful combination of all three strategies is required. The instruments examined in detail in section 3 and the instruments looked at for comparison purposes in section 3.3 all - in varying ways - integrate efficiency and/or sufficiency strategies. ${ }^{2}$

2 Instruments that follow a pure consistency strategy were not investigated. 


\section{Instruments with characteristics of a sufficiency approach}

\subsection{Introducing the case studies}

The instruments examined show the following features:

- They develop on private initiative without pressure from above (that is, not upon set instructions from federal or local authorities) and from the bottom-up.

- They are closely related to environmental consciousness and sustainable practices. That is, they aim towards a direct or indirect effect on the environment and an ecological revolution in daily living.

- They integrate environmental policy goals in their activities, or do so at least at the start.

- Participation is on a voluntary basis.

- Participants accept higher costs and/or changes in lifestyle.

- They thus contain the fundamental elements of a sufficiency approach.

The instruments showing sufficiency characteristics that we examined fall in the typology under service and infrastructure or communication and diffusion instruments. A sufficiency strategy can be followed and implemented by individuals, households, or communities. At the level of the individual, we will look at car sharing (Mobility Switzerland), at the level of households we examine the Household EcoTeam Programme of Global Action Plan (GAP), and at the community level we turn to the Model Bicycle City of Münsingen (Veloville). The following describes the most important aspects of these instruments as well as their goals (sections 3.1.1 to 3.1.4) and assesses their ecological effects and market potential (section 3.2.). A comparison to the ecological impacts and market potentials of economic instruments and command and control instruments follows in section 3.3. Finally, success factors for raising the market potential are outlined (section 3.4).

\subsubsection{Reducing traffic by sharing cars (Mobility Switzerland)}

Fifteen years ago, the idea that several persons could share one car in order to save on costs and to reduce environmental impact gained organisational impetus with the forming of two associations, Sharecom and ATG (Autoteilet Genossenschaft). The idea continued to grow and develop, and since 1993, it has been promoted and supported, financially and conceptually, by the federal government's energy action programme Energy 2000. ${ }^{3}$ In 1997 the two organisations merged to form Mobility CarSharing Switzerland. By the end of 1999, 1,200 cars were available for use by approximately 30,000 participants in the scheme.

Customers, both individuals and companies, use car sharing vehicles in different ways. Private individuals (about 83\%) tend to use the vehicles mainly for leisure-time activities and also for goods transport or big shopping trips. Companies use the cars for business trips, but for lei-

\footnotetext{
See also the study by BÄTTIG AND BALTHASAR.
} 
sure-time activities and shopping as well. At present, Mobility CarSharing's offer of cars for holiday travel, daily shopping, and the commute to work have not found much response. This will change in future, however, particularly with regard to holiday trips, as a result of collaboration with the Swiss Federal Railways and other public transportation providers. Participants will have at their disposal car sharing vehicles, which are often stationed at the railway stations, all over Switzerland (Muheim, 1998).

Theoretically, there are 1.7 million potential customers for car sharing. They range in age from 18 to 74, are in the possession of a driver's license, and live in developed zones of municipalities of over 2,000 residents. In a survey of this group, 613,000 people stated that they could well or very well imagine participating in the scheme. This corresponds to $9 \%$ of the population of Switzerland (Muheim, 1998).

\subsubsection{Reducing household related environmental problems (Global Action Plan)}

GAP was founded in 1989 as a non-profit organisation in the United States. GAP's main goal is to promote sustainable lifestyles through educational instruction in easy and concrete resourceefficient practices. In 1990, GAP set the target to reduce water use by a third, household waste by $75 \%$, and $\mathrm{CO}_{2}$ emissions by $20 \%$ by the year 2000 . Programmes were developed for communities, households, schools, and companies. The GAP strategy is based upon Roger's Diffusion of Innovations theory (Rogers, 1995), which is a model of the gradual acceptance of new ideas in society. ${ }^{4}$

In GAP's Household EcoTeam Programme, five to eight households form a team to adopt resource-efficient practices in the areas of waste, water, energy, mobility, and consumer behaviour with the aid of a workbook of easy-to-use suggestions for practice. ${ }^{5}$ In order to demonstrate the results of the programme and their own actions, participants measure their usage at the start and at the end of the household programme. The programme is built on three pillars: specific suggestions for practice based on sustainability goals, active support and advice to teams, and feedback by means of collecting results and reporting back to the teams.

In the mobility sector, GAP suggests a number of measures to reduce mobility-related environmental impacts. They include giving up driving your own car and switching to public transportation; giving up driving in part; fuel-saving driving practices and adherence to speed limits; the forming of commuter car pools; purchase of a more fuel-efficient vehicle or electromobile;

\footnotetext{
The model identifies five different phases of diffusion (innovators, early adopters, early majority, late majority, laggards) and describes the groups within a population that tend to accept an innovation at each phase. As soon as an innovation has been adopted by enough individuals within a particular group, it achieves the "critical mass", and the innovation's further rate of adoption becomes self-sustaining. GAP was designed to facilitate fast development of this critical mass in "early adopter" groups, neighbourhoods, and communities (Market Street Research Inc., 1996).

5 For example, weather-strip doors and windows, turn hot water boiler temperature to 55 to 60 degrees, replace lightbulbs with energy-saving bulbs, separate trash, install a flush-interrupter to toilet tank, calculate commuter expense, experiment with using public transportation to work, choose durable products, and so on.
} 
more rational and efficient planning of business trips; and foregoing flights to vacation spots and long holiday trips by car. ${ }^{6}$

\subsubsection{Promoting bicycle mobility by a community based action (Veloville Münsingen)}

Münsingen, the regional centre of the Aare Valley between Bern and Thun, has a population of more than 10,000 . With a volume of 20,000 vehicles, traffic jams the centre of town every morning and evening. As a consequence of the large proportion of traffic in the town itself, alternatives within the town were required.

In the framework of the project "Traffic Management in Energy Towns", initiated by the sponsor association Energiestadt ${ }^{7}$ in collaboration with the federal energy action programme Energy 2000, an energy-saving campaign was started in Münsingen. The conception and planning of the campaign was turned over to a broad-based committee (representatives from town administration, business, local citizens). The committee, in co-operation with local businesses, decided to hold a special bicycle stand event.

On the day of the event in May 1995, bicycle stands were set up in front of local shops and stores. Münsingen was christened "Veloville" (bicycle city), and new, blue Veloville markers were added to the official town signs. Information was distributed to all households, and local clubs and associations held numerous special bicycle events. The bicycle stand campaign was a success with the public and was received with great interest by the national media. The results of the campaign were evaluated in an interview survey of participants and external observers (INFRAS, 1997).

6 Within the framework of the Swiss Prority Programme Environment (Swiss National Science Foundation), the Centre for General Ecology IKAÖ, IKF, University of Zurich, and INFRAS collaborated in 1997/1998 on a written survey of GAP participants, whereby the present authors investigated the topic of mobility. In addition to questions about everyday practices, the participants were asked about their choice of transportation, travel distances, political attitudes, and attitudes towards GAP measures in the area of mobility. See here also BRUPPACHER AND ULLI-BEER and VATTER ET AL.

7 Energiestadt (Energy City) was founded in 1989 and is sponsored today by NGOs and the Swiss Federal Office of Energy. 


\subsection{4. $\quad$ Summarising the case studies}

The case studies can be summed up as follows:

Table 1: The action programmes at a glance.

\begin{tabular}{|c|c|c|c|}
\hline Case study & Sponsor or provider & Goals & Implementation \\
\hline GAP & Independent NGO & $\begin{array}{l}\text { Aims to promote the de- } \\
\text { velopment of environ- } \\
\text { mentally sustainable } \\
\text { lifestyles }\end{array}$ & $\begin{array}{l}\text { Simple and easy-to-do } \\
\text { instructions for practices } \\
\text { that can be applied in } \\
\text { groups }\end{array}$ \\
\hline $\begin{array}{l}\text { Mobility } \\
\text { CarSharing }\end{array}$ & Private association & $\begin{array}{l}\text { Aims at cost savings and } \\
\text { reduction of environ- } \\
\text { mental impact by having } \\
\text { many persons share a } \\
\text { small number of vehicles }\end{array}$ & $\begin{array}{l}\text { Nation-wide fleet of ve- } \\
\text { hicles and combined } \\
\text { mobility through col- } \\
\text { laboration with public } \\
\text { transport organisations }\end{array}$ \\
\hline $\begin{array}{l}\text { Veloville } \\
\text { Münsingen }\end{array}$ & $\begin{array}{l}\text { Broad based working } \\
\text { committee of adminis- } \\
\text { trators, businesses, and } \\
\text { citizens }\end{array}$ & $\begin{array}{l}\text { Aims to improve the traffic } \\
\text { situation within the } \\
\text { municipality }\end{array}$ & $\begin{array}{l}\text { Numerous events in a } \\
\text { bicycle campaign and a } \\
\text { commitment from the } \\
\text { municipality to make the } \\
\text { centre more bicycle- } \\
\text { friendly }\end{array}$ \\
\hline
\end{tabular}

\subsection{Possible ecological outcome of instruments incorporating a sufficiency approach}

\subsubsection{Mobility CarSharing}

While initially mainly people who did not own cars joined the car sharing organisation, there have been an increasing number of new memberships in connection with the purchase of a car. Total mobility in kilometres has not changed significantly as a result of CarSharing membership. Whether members or non-members of CarSharing, people travel a distance of between 13,000 and 16,000 kilometres by private and public transportation per year. Only when people give up their cars as a result of joining the CarSharing scheme is their travel reduced by any notable amount (see Figure 1).

By increasing the proportion of mobility by public transport, people who have joined CarSharing have reduced their energy use (fuel) on average by 4,200 megajoules (MJ) per year (from $14,000 \mathrm{MJ}$ to $9,800 \mathrm{MJ}$ ). With about 30,000 active customers at the end of 1999 , this resulted in total energy savings of approximately 130 terajoules (TJ) per year, which is more or less equal to the annual power consumption of a small municipality with a population of 5,000 residents. 


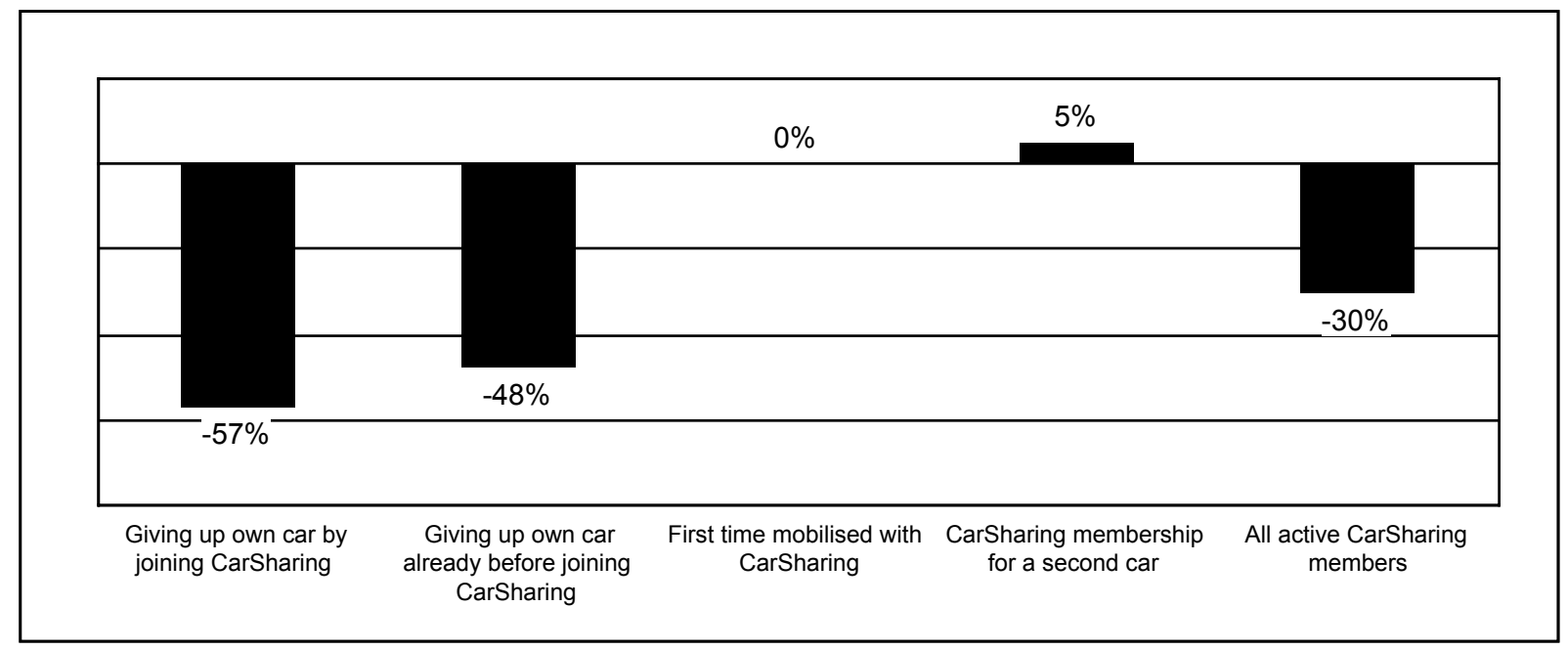

Figure 1: Energy savings according to customer category (source: Muheim, 1998). Through joining CarSharing, the average personal energy requirements for private motorised and public transportation can be greatly reduced $(100 \%=$ without CarSharing $)$.

With about 22,000 MJ fuel requirements per year, persons using their own private automobiles have a higher energy consumption than participants in CarSharing. If these potential customers join in, the average energy savings increases, because the overall impact of CarSharing depends on the number of users and the proportion of those who give up car ownership. As the proportion of people with their own cars decreases, the level of customer-specific energy savings increases to an estimated figure of 6,400 MJ per year. If the theoretical customer potential of over 600,000 interested persons were fully exploited, CarSharing could reduce motorised mobility by 1,700 million kilometres ( $2.3 \%$ of the total personal mobility demand). Moreover, distances travelled by individual cars are travelled in a more energy-efficient manner due to the fuel-saving fleet of cars. The specific fuel requirements decrease by $17 \%$. All together, the result is a reduction of fuel requirements by a total of 3.9 petajoules $(\mathrm{PJ})$ per year, or about $3 \%$ of total fuel consumption by private motorised transport (Muheim, 1998).

\subsubsection{Global Action Plan}

In Switzerland more than 1,000 households have worked through the GAP Household EcoTeam Programme to date. According to GAP 1996, the results of over 100 GAP teams yielded savings of $18 \%$ in trash production, $14 \%$ in water use, $8 \%$ in energy use, and $13 \%$ in $\mathrm{CO}_{2}$ emissions through motor travel. These figures reflect only the energy savings during the course of the programme, however, and do not include eventual continued savings. Significant improvements can be achieved mainly in the areas of waste and consumption, with partial success in the area of water. On the other hand, most of the suggestions in the areas of mobility and energy can not be put into practice. Problems arose whenever implementation of the measures involved high investment costs, great efforts in terms of time, significant reduction of comfort, and inadequate or 
lacking infrastructures. Other measures that were difficult to put into practice were as a rule those that required co-operation with other, less interested persons (Känel et al., 1998).

According to our survey at the start of the programme, participants tend to question the effectiveness of the measures proposed by GAP. Participants thus find it difficult to apply the practices suggested for the area of mobility, as they assess the potential effectiveness to be low. Over half of the participants are willing to practice the measures of careful, fuel-saving driving and adherence to speed limits (see Table 2). At the same time, however, these two measures are judged to be the least effective measures with regard to the environment. Participants find measures more effective that involve total renunciation of cars, respectively a shift to the use of public transportation. On total then, the participants demonstrate a moderate degree of willingness to put the suggested measures into practice.

Table 2: GAP participants' assessment of GAP measures in the mobility sector.

\begin{tabular}{|c|c|c|c|c|c|}
\hline \multirow[t]{2}{*}{ GAP activity } & \multirow{2}{*}{$\begin{array}{l}\text { What measure do } \\
\text { you intend to put } \\
\text { into practice in the } \\
\text { coming months? }\end{array}$} & \multicolumn{4}{|c|}{$\begin{array}{l}\text { What is your assessment of the environmental } \\
\text { effectiveness (impact) of the measure? }\end{array}$} \\
\hline & & low & moderate & high & no response \\
\hline $\begin{array}{l}\text { Give up driving altogether, } \\
\text { shift to public transportation }\end{array}$ & $40 \%$ & $8 \%$ & $11 \%$ & $75 \%$ & $6 \%$ \\
\hline Give up driving in part & $41 \%$ & $10 \%$ & $73 \%$ & $11 \%$ & $6 \%$ \\
\hline $\begin{array}{l}\text { Careful, fuel-saving driving } \\
\text { and adherence to speed } \\
\text { limits }\end{array}$ & $51 \%$ & $29 \%$ & $54 \%$ & $11 \%$ & $6 \%$ \\
\hline Form commuter car pools & $0 \%$ & $8 \%$ & $60 \%$ & $17 \%$ & $14 \%$ \\
\hline $\begin{array}{l}\text { Purchase a fuel-efficient car } \\
\text { or electromobile }\end{array}$ & $2 \%$ & $16 \%$ & $46 \%$ & $24 \%$ & $14 \%$ \\
\hline $\begin{array}{l}\text { More rational and efficient } \\
\text { planning of business trips }\end{array}$ & $6 \%$ & $19 \%$ & $40 \%$ & $29 \%$ & $13 \%$ \\
\hline $\begin{array}{l}\text { Forego flights to vacation } \\
\text { destinations and long holi- } \\
\text { day trips by car }\end{array}$ & $25 \%$ & $10 \%$ & $16 \%$ & $68 \%$ & $6 \%$ \\
\hline
\end{tabular}

Planned implementation of measures and assessment of their effectiveness (survey of 63 participants in the GAP programme). 
No definite prognosis can be made as to how long the measures in the area of mobility remain effective. Due to the problems in implementation, the medium- and long-term effects of the measures are certainly lower than the figures provided by GAP. ${ }^{8}$ There is an additional factor besides: according to our survey, GAP participants already drive only half the average Swiss personal travel distance (about 7,000 km per year), and they are more conscious of environmental issues.

If we assume an optimistic amount of energy savings of about $10 \%$, a potential of 10,000 participants, ${ }^{9}$ and effects maintained over a longer term for 10 to $20 \%$ of all participants, GAP could achieve a long-term maximum of 0.2 to 0.4 PJ savings in energy per year. ${ }^{10}$

\subsubsection{Bicycle and pedestrian model town (Veloville)}

With its declaration of a Veloville, Münsingen has committed itself to long-term promotion of the bicycle. Further campaign events are planned, and issues important to pedestrians have also gained weight. The survey interviews showed that the population would be receptive to a discussion and an examination of traffic and the choice of the means of travel.

Despite that, no change in behaviour on the basis of Veloville could be established (INFRAS, 1997). Members of the working committee do not see any reduction of traffic on the main road on the contrary, they believe that the traffic volume has increased. For this reason, no quantitative figures on energy savings caused by the campaign can be derived.

\subsection{A comparison with command-control and economic instruments}

A number of further instruments are being implemented in the mobility sector or are planned for the near future. There are communication and diffusion instruments (propagating ecological driving) on the one hand, and command and control instruments (speed limits), and economic instruments (petrol price increase, energy tax) on the other. The following energy savings can be achieved in comparison to the instruments examined in section 3.2 (see also Figure 2):

- Ecological driving: Another measure supported by the federal energy action programme Energy 2000 is "eco-driving". "If appropriate learning contents are included in driver education courses, a clear and lasting reduction in fuel consumption can be achieved (IAP, 1995). Over the long term, in comparison with the traditional style of driving, eco-driving can yield fuel savings of 10 to $15 \%$ (Energie 2000, 1998). With 40,000 new drivers trained in eco-driving

8 According to Graf 1997, 40\% of participants in a survey report that energy savings have been maintained up to the present date, while $55 \%$ do not respond and thus appear to be sceptical about how long the measures remain effective. The figure for mobility measures must be significantly lower.

To be achieved around the year 2010 based on the current diffusion rate.

10 Assumed: 7,000 km per year and person, 8.51 petrol per $100 \mathrm{~km}$.

11 Eco-driving is a fuel-efficient and thus more economical and more environmentally friendly style of driving (correct choice of gear, low engine revolution driving, avoidance of unnecessary braking by means of a defensive driving style, regular tire pressure checks, and so on). 
annually (in 1999 about half of all new drivers), an energy savings of $200 \mathrm{TJ}$ can be reached. Each year, of course, there are more new drivers, and this will increase the energy savings through eco-driving. If all drivers in Switzerland were trained eco-drivers, over 20 million PJ of fuel energy could be saved (at 10\% of the fuel requirements).

- Speed limits in residential neighbourhoods: A comprehensive reduction of the speed limit in residential neighbourhoods from 50 to $30 \mathrm{~km}$ per hour could result not only in increased traffic safety, but also in fuel savings (INFRAS, 1998). This is based on the assumption that fuel consumption decreases at slower speeds. On the whole, we could reckon with energy savings in the amount of about $0.2 \mathrm{PJ}$ annually. ${ }^{12}$

- Price increase on fuel: A comprehensive introduction of a fuel tax of CHF 0.50 per litre would lead to a reduction in distance travelled by car or a change in driving behaviour. A reduction in energy consumption of 10 PJ per year could be achieved (INFRAS, 1998).

- $\mathrm{CO}_{2}$ Law: The effects of the $\mathrm{CO}_{2}$ Law on the transport sector are assessed in the framework of the energy perspectives of the Swiss Federal Office of Energy (Prognos, 1996). In comparison with the reference scenario (implementation of all approved measures), the $\mathrm{CO}_{2} \mathrm{Law}$ can achieve energy savings of about 41.5 PJ per year by 2030 (-12\% compared to the reference scenario).

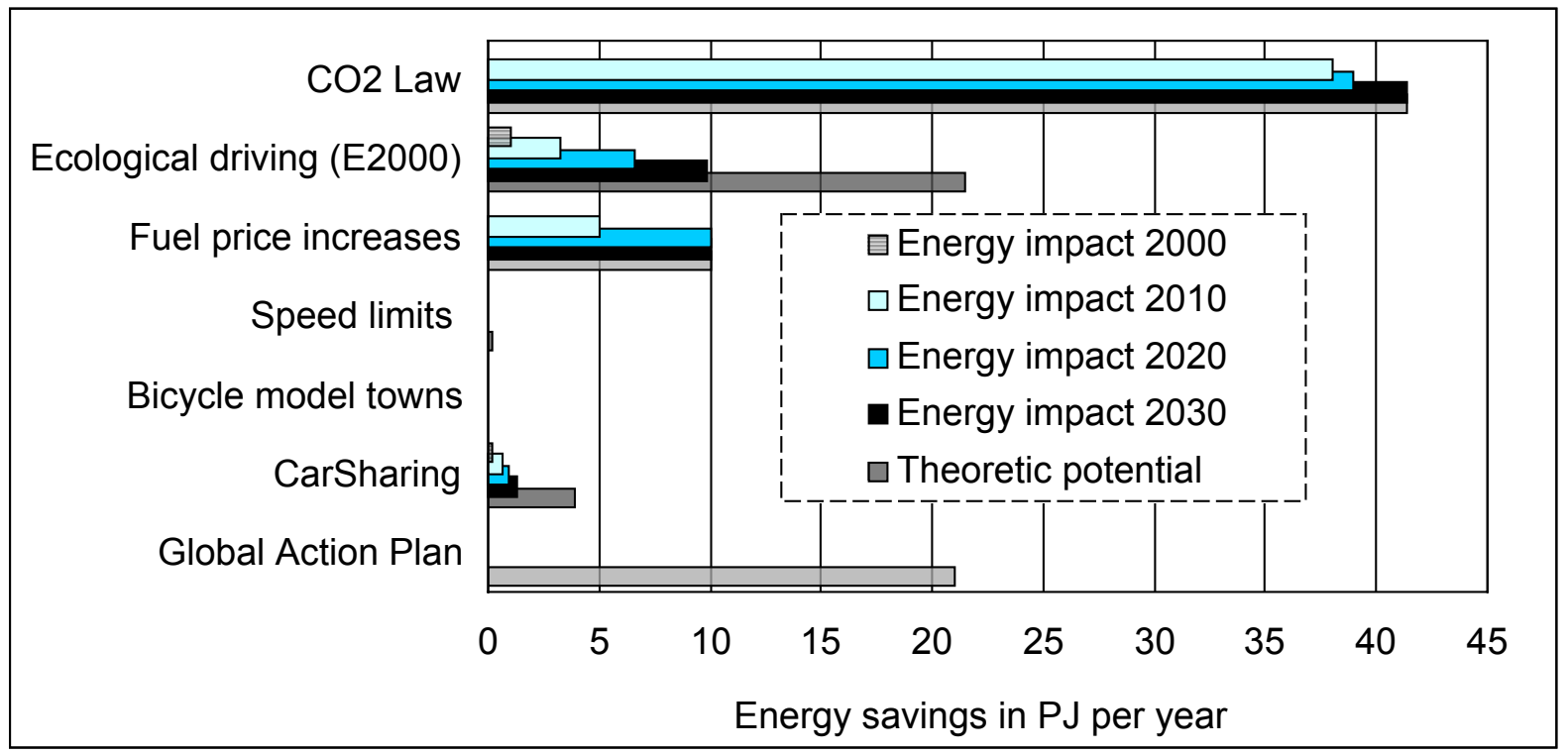

Figure 2: Long-term effects of measures in the transport sector if the potentials are fully exploited.

12 In the spring of 2000, both the Federal Council and the National Council voted against a general reduction of speed limits in residential neighbourhoods. 
Figure 2 shows that the effects in terms of energy reduction that can be yielded by federal government or cantonal economic instruments or command and control instruments (fuel price increase, implementation of the $\mathrm{CO}_{2}$ Law) as well as communication instruments (ecological driving) that follow an efficiency strategy are considerably greater than the effects of the instruments with characteristics of a sufficiency strategy that we examined above.

\subsection{Success factors and barriers for further implementation}

For the goals set by GAP to be achieved through the measures they propose, two factors are extremely important. First, a change in lifestyle must be sustained over the long term. However, in the mobility sector in particular, the GAP measures are very difficult to put into practice. The barriers appear to include the high investment costs, high expenditure of time, and great sacrifice in terms of comfort. Whether the measures would remain effective in the long term has not been examined in a comprehensive manner. It is significantly easier to apply the measures once and in a limited fashion than to maintain the behaviours through time. ${ }^{13}$ It is also probable that a change in lifestyle is more difficult for a person who is not very conscious of environmental concerns than for a person who has a high level of awareness. For this reason, we hardly expect to see a comprehensive change in lifestyles.

As the second important factor, a widespread diffusion of the programme is essential. According to GAP, a critical mass of 10 to $20 \%$ of the population is required for successful implementation of the programme, and this could be achieved in three to four years. However, this has not taken place so far. It appears to be difficult to find a sufficient number of interested persons. This was apparent also in our own survey. GAP participants make only cautious predictions in this regard, and they tend to see a high enough potential for participation only in their own circles of friends. The critical mass could hardly be reached in that way. As long as the two factors - changes in lifestyle and diffusion - can not be better implemented, the ecological contribution will remain quite modest.

The situation is somewhat different with car sharing. Car sharing can contribute significantly to environmental sustainability in the mobility sector. For this, the attempt has to be made to tap the full customer potential (600,000 persons). An analysis of present-day users' reasons for participating in the Mobility CarSharing scheme shows a shift from ideological to more pragmatic and cost-oriented arguments. Mobility behaviour changes most with participation if, at the same time, members give up the use of their private cars. This means that car sharing can be made more attractive using two approaches. On the one hand, CarSharing itself can improve the quality and comprehensiveness of its services, for this has a positive effect on the rate of customer growth. On the other hand, positive effects can be achieved through improving the services and status of public transportation and non-motorised means of mobility. A tough barrier to mem-

13 However, a recent study in Holland indicates that behaviour changes resulting from GAP participation are not only maintained through time, but also become stronger (see here also BRUPPACHER AND ULLI-BEER). 
bership in a car sharing scheme is fear of a loss of convenience and comfort. Potential customers also place high value on a wide choice of vehicles and safe, clean, and well-equipped cars. The success of the instruments examined above is thus dependent upon internal, programme-specific and external, programme-independent factors. For campaigns in a small context, such as Veloville Münsingen, broad based support and a good information policy seem essential. For national action programmes like GAP or CarSharing, ease of application and the optimisation of framework conditions in the mobility sector must be underlined.

\section{Summary and conclusions towards an optimal combination of instruments}

The research on strategies for sustainable development has shown that both efficiency and sufficiency strategies have a role to play. Consistency - the economical management of resources by means of a comprehensively conceived economic cycle - must also be taken into consideration, particularly in the development of new technologies. In the face of growing consumption, technological innovations and increased efficiency alone will not suffice, however, to master ecological problems. What is more, efficiency gains are easily negated by growth effects and have in the past led to an increased demand for products and ultimately to an increase in resource use. At the same time, efficient products and services will most likely succeed on the market much more quickly than any shift in values towards sufficiency can take place. In addition, people will continue to show a wide spectrum of individual differences in future. While some people base their self-definition on their material possessions, others tend to seek fulfilment by means of contacts to other people and independent decisions over time. Thus, strategies of the efficiency revolution and the consistency revolution will succeed only if a sufficiency revolution occurs as well. Here community based, democratically organised self-imposed restriction through the sharing of goods can play an important role.

The service, infrastructure, and communication instruments in the mobility sector examined above - car sharing (Mobility CarSharing Switzerland), Global Action Plan's Household EcoTeam Programme, and the Bicycle City of Münsingen (Veloville) - show the characteristics of the sufficiency approach. They encourage people to give up their personal cars, to change over to public transportation, or to travel more by bicycle. In comparison to economic or command and control instruments implemented by the authorities that show the characteristics of the efficiency approach, the "sufficiency instruments" yield significantly smaller measurable ecological effects. This is because up to now, sufficiency instruments appeal primarily to people who are already environmentally conscious, while government instruments as a rule apply to the entire population. Only a small part of the population has been reached by sufficiency instruments, which demand a greater willingness to incur costs, seem to restrict the personal freedom to act, and demand a change in lifestyle. If the theoretical customer potential of such instruments were more fully exploited, the ecological effects would be more significant. 
A feasible way to strengthen the sufficiency instruments in the mobility sector that we examined would be to implement appropriate economic and/or command and control instruments. Price measures can be seen as the key to changes in mobility behaviour. This has also been acknowledged by earlier studies that concluded that instruments integrating price incentives are much more effective than sufficiency approaches or command and control instruments, especially in the energy and transport sector. These studies, however, also conclude that environmental consciousness and voluntary self-commitments can influence environmental action - last but not least in the sense of an important parameter for political decision-making processes (Diekmann, 1994; Frey and Busenhart, 1994).

Therefore, the energy policy planned for Switzerland that foresees price increases for fossil fuels promises to be an optimal basis for reinforcing "sufficiency instruments". Once the government has established these new framework conditions, participation in Mobility CarSharing or GAP will become more attractive to participants from an economic perspective as well.

However, as long as fuel prices remain low, the true costs of mobility are not borne, and private motorised transport continues to receive high priority, the growth in private traffic volume can only be checked by means of a big boost to the attractiveness of public transportation services and through the implementation of measures by federal and cantonal authorities. And so for the meantime, for sufficiency instruments to succeed, it is important that participants continue to show a willingness to pay the higher price of environmentally friendly products and services and a readiness to adopt changes in their lifestyles.

\section{References}

BCSD/Business Council for Sustainable Development (1994) Getting eco-efficient. International BCSD/UNEP, Institute for Environment and Development. World Business Council for Sustainable Development. Online in the WWW: <http://www.wbcsd.com>

BFS/Bundesamt für Statistik (1999) Statistisches Jahrbuch Schweiz. Bern.

Bringezu, S. (1999) Aus weniger mach mehr. Über den Zusammenhang von Effizienz und Umweltverbrauch. Politische Ökologie, 17/62: 14-17.

BUWAL/Bundesamt für Umwelt, Wald und Landschaft and BFS/Bundesamt für Statistik (1997) Umwelt in der Schweiz 1997 - Daten, Fakten, Perspektiven. Bern.

Energie 2000 (1998) 8. Jahresbericht des Aktionsprogramms Energie 2000. Beilagenband 1. Bern.

Diekmann, A. (1994) Umweltbewusstsein oder Anreizstrukturen? Empirische Befunde zum Energiesparen, der Verkehrsmittelwahl und zum Konsumverhalten. In: Kooperatives Umwelthandeln, Modelle, Erfahrungen, Massnahmen, Diekmann, A. and Franzen, A. (eds.), Rüegger Verlag, Chur, Zürich.

Fischer, W. (1995) Nachhaltige Entwicklung - eine Norm für die Gestaltung unserer Zukunft. Online in the WWW: <http://www.zam.kfa-juelich.de/tff/tff_sustaina.html>

Frey, B.S. and Busenhart, I. (1994) Umweltpolitik: Ökonomie oder Moral. In: Kooperatives Umwelthandeln, Modelle, Erfahrungen, Massnahmen, Diekmann, A. and Franzen, A. (eds.), Rüegger Verlag, Chur, Zürich.

GAP/Global Action Plan Schweiz (1996) Pressespiegel. Zürich.

Graf, E.O. (1997) Energiesparaktionen. BFE/Bundesamt für Energie, Bern.

Hofmeister, S. (1999) Über Effizienz und Suffizienz hinaus. Zur methodischen Weiterentwicklung des Stoffstrommanagements mit Bezug auf Nachhaltigkeit. Politische Ökologie, 17/62: 34-38.

Hofmeister, S., Huber, H. and von Gleich, A. (1999a) Wege nach Ökotopia. Kann Nachhaltigkeit ohne Sparsamkeit erreicht werden? Eine Gesprächsrunde. Politische Ökologie, 17/62: 8-12. 
Huber, J. (1995) Nachhaltige Entwicklung durch Suffizienz, Effizienz und Konsistenz. In: Nachhaltigkeit in naturwissenschaftlicher und sozialwissenschaftlicher Perspektive, Fritz, P., Huber, J. and Levi, H.-W. (eds.), Stuttgart.

IAP/Institut für Angewandte Psychologie (1995) Evaluation des Projekts "Eco-Fahrweise: Fahrlehrer- und Expertenausbildung". Zürich.

INFRAS (1997) Evaluation Energiesparaktionen im Verkehr auf Gemeindeebene - Beispiel "Veloville" Münsingen. Energie 2000, Ressort Treibstoffe, Bern.

INFRAS (1998) Kosten-Wirksamkeiten von Umweltschutzmassnahmen im Verkehr. Forschungsauftrag 41/96 auf Antrag der Vereinigung Schweizerischer Verkehrsingeniere, SVI, Zürich.

Känel, E., Magun, B., Öhri, R. and Sanchez, A. (1998) Umweltverantwortliches Alltagshandeln beim Global Action Plan: die Bedeutung sozialer Netze. Schriftenreihe Studentische Arbeiten, Nr. 11. IKAÖ, Universität Bern.

Market Street Research Inc. (1996) The market potential for the household ECOTEAM Programme, prepared for GAP, Northampton, MA.

Muheim, P. and Partner (1998) CarSharing - der Schlüssel zur kombinierten Mobilität. Evaluation der Unterstützung des CarSharing durch Energie 2000. BFE/Bundesamt für Energie, Bern.

Prognos (1996) Energieperspektiven der Szenarien I bis III, 1990 - 2030. BFE/Bundesamt für Energie, Bern.

Rogers, E. (1995) Diffusion of innovations. Fourth Edition. The Free Press, New York, London, Toronto.

Schumacher, L. (1997) Strategien zur Erreichung einer nachhaltigen Entwicklung. Online in the WWW: $<$ http://www.ph-freiburg.de/wirtscha/schumac4.htm>

Stahel, W.R. (1999) Geteiltes Notebook - doppelte Freude? Nutzenorientierung als Strategie für eine ressourcenschonende Gesellschaft. Politische Ökologie, 17/62: 63-66.

Weizsäcker, E.U., Lovins, A.B. and Lovins, L.H. (1997) Factor four. Doubling wealth, halving resource use. Earthscan Publications LTD, London. 


\section{List of Authors}

Mauch Ursula, lic. phil. nat

Mauch Consulting, Ruchweid 23, CH-3917 Oberlunkhofen

Tel: ++41 (56) 63415 27; Fax: ++41 (56) 6343140

eMail: umauch@pop.agri.ch

North Nicole, dipl. geogr.

INFRAS, Gerechtigkeitsgasse 20, Postfach, CH-8039 Zurich

Tel: ++41 (1) 20595 95; Fax: ++41 (1) 2059599

eMail: nicole.north@infras.ch

Pulli Raffael, dipl. natw. ETH

INFRAS, Gerechtigkeitsgasse 20, Postfach, CH-8039 Zurich

Tel: ++41 (1) 20595 95; Fax: ++41 (1) 2059599

eMail: raffael.pulli@infras.ch

\section{Translator}

Russon Ellen, lic.phil.

24 Putting Green Circle East Sandwich, Massachusetts, USA-02537

Tel: ++1 (508) 36210 41; Fax: ++1 (508) 4280701

eMail: ellenrusson@earthlink.net 